\title{
Gold/palladium (Au/Pd) Bimetallic Thin Film Deposition by Radio Frequency Magnetron Sputtering Technique
}

\author{
Volkan ŞENAY ${ }^{1 *}$
}

\begin{abstract}
In this study, two gold/palladium (Au/Pd) thin films having $20 \mathrm{~nm}$ and $80 \mathrm{~nm}$ thickness values were simultaneously deposited on glass substrates by adjusting target-substrate distance via radio frequency (RF) magnetron sputtering technique. The optical and surface properties of the produced thin films were investigated by using UV-VIS spectrophotometer, interferometer, tensiometer and atomic force microscope. The effects of film thickness on the investigated properties of the thin films were reported.
\end{abstract}

Keywords: Bimetallic thin films, optical properties, surface properties, low surface free energy

\section{Radyo Frekans Magnetron Sıçratma Tekniği ile Altın/Paladyum (Au/Pd) Bimetalik İnce Film Biriktirme}

ÖZET: Bu çalışmada, $20 \mathrm{~nm}$ ve $80 \mathrm{~nm}$ kalınlığa sahip iki adet altın/paladyum ( $\mathrm{Au} / \mathrm{Pd})$ ince film, eş zamanlı olarak radyo frekans (RF) magnetron sıçratma tekniği ile hedef-alttaş mesafesinin ayarlanmasıyla cam alttaşlar üzerinde biriktirilmiştir. Üretilen ince filmlerin optik ve yüzey özellikleri UV-VIS spektrofotometre, interferometre, tansiyometre ve atomik kuvvet mikroskobu kullanılarak incelenmiştir. Film kalınlığının, ince filmlerin incelenen özellikleri üzerindeki etkileri rapor edilmektedir.

Anahtar Kelimeler: Bimetalik ince filmler, optik özellikler, yüzey özellikleri, düşük serbest yüzey enerjisi

\footnotetext{
${ }^{1}$ Volkan ŞENAY (Orcid ID: 0000-0002-6579-2737), Bayburt University, Department of Opticianry, Bayburt-Turkey *Sorumlu Yazar / Corresponding Author: Volkan ŞENAY, e-mail: vsenay@bayburt.edu.tr 


\section{INTRODUCTION}

Preparation of metallic nanoparticles (NPs) with various compositions, structures, shapes and sizes is a matter of interest due to their unique catalytic, electronic, and optical properties (Fedrigo et al., 1993; Kreibig and Vollmer, 1995; Palpant et al., 1998; Bonet et al., 1999). During the past years, more attention is paid to the preparation of bimetallic NPs that are composed of two different metal elements (Szabo and Vollath, 1999; Hodak et al., 2000; Hodak et al., 2000; Maye et al, 2000; Shao et al., 2015; De Yuso et al., 2017). Because, they can exhibit peculiar electronic, optical, and catalytic properties that are absent in the corresponding monometallic NPs (Cybula et al., 2014). Therefore, they are expected to have potential applications in many technologies such as optoelectronic nanodevices, catalysts, and chemical sensors (Kan et al., 2003; Yi et al., 2005; Ferrer et al., 2007). Bimetallic gold/palladium (Au/Pd) NPs can be considered one of the most popular among various alloy nanomaterials (Toshima et al., 1992; Toshima and Yonezawa, 1998; Henglein, 2000; Mizukoshi et al., 2000; Wu et al., 2001; Kan et al., 2003; Li et al., 2004; Zhang and Yin, 2012). Au/Pd, bimetallic solid solution with their atoms located in nanostructures provides synergistic interaction, which leads to enhanced electrical, physical, and chemical properties (Mallikarjuna et al., 2019). Consequently, bimetallic $\mathrm{Au} / \mathrm{Pd} \mathrm{NPs}$ finds wide applications in different fields (Chowdhury et al., 2018). At this point, magnetron sputtering technique is very helpful as an effective way which exhibit properties of great technological importance. In this paper, the synthesis procedure and some physical properties of the $\mathrm{Au} / \mathrm{Pd}$ bimetallic thin films fabricated by $\mathrm{RF}$ magnetron sputtering technique are reported. As far as is known, there is a study on the production of $\mathrm{Au} / \mathrm{Pd}$ thin films by an another physical deposition technique (Parajuli et al., 2019). However, there is no study in the literature that reports the optical and surface properties of $\mathrm{Au} / \mathrm{Pd}$ thin films produced by $\mathrm{RF}$ magnetron sputtering technique.

\section{MATERIAL AND METHODS}

\section{Fabrication of thin films}

In the current research, two $\mathrm{Au} / \mathrm{Pd}$ thin films were simultaneously deposited on glass microscope slides positioned at $30 \mathrm{~mm}$ and 45 mm away from the sputter gun by means of RF magnetron sputtering technique. A $99.99 \%$ pure $\mathrm{Au} / \mathrm{Pd}$ target was used as source material. The dimensions of the glass substrates were $75 \mathrm{~mm}$ $\times 25 \mathrm{~mm} \times 1 \mathrm{~mm} .99 .99 \%$ purity argon (Ar) gas was the buffer gas. $13.56 \mathrm{MHz}$ RF power was adjusted to $125 \mathrm{~W}$. Working pressure was approximately $3 \times 10^{-1}$ Torr. The deposition process was carried out for 60 minutes under these conditions. Deposition parameters are summarized in Table 1.

Table 1. Sputtering parameters of $\mathrm{Au} / \mathrm{Pd}$ thin films

\begin{tabular}{llll}
\hline RF power $(\mathrm{W})$ & Substrate to target distance $(\mathrm{mm})$ & Working pressure (Torr) & Time (min)
\end{tabular}

\section{Characterization of thin films}

In order to determine the thickness and the refractive index values of the deposited $\mathrm{Au} / \mathrm{Pd}$ thin films, surface reflections were measured in the wavelength range of $400-1000 \mathrm{~nm}$ by a Filmetrics F20 thin film analyzer. The transmittance and absorbance spectra of the thin films were obtained by an UNICO UV-VIS spectrophotometer between the wavelengths 300 $\mathrm{nm}$ and $1000 \mathrm{~nm}$. The surface morphologies of the thin films were investigated using an Ambios Q-Scope atomic force microscope (AFM). The 
surface contact angles of water drop on the thin films and the surface free energies of the thin films were measured by using an Attension Tensiometer.

\section{RESULTS AND DISCUSSION}

\section{Reflectometry studies}

The obtained reflectance spectra of the produced $\mathrm{Au} / \mathrm{Pd}$ thin films are presented in Figure 1. The reflectance spectrum of the bare microscope slide is also given in the same figure for better comparison. The film thickness values estimated from the reflectance analysis were approximately $20 \mathrm{~nm}$ and $80 \mathrm{~nm}$. It was observed that the target-substrate distance affected the film thickness as expected and the thickness value decreased with the increasing target-substrate distance. The reflectance value increased with the increasing film thickness due to the metallic property of the produced thin films.

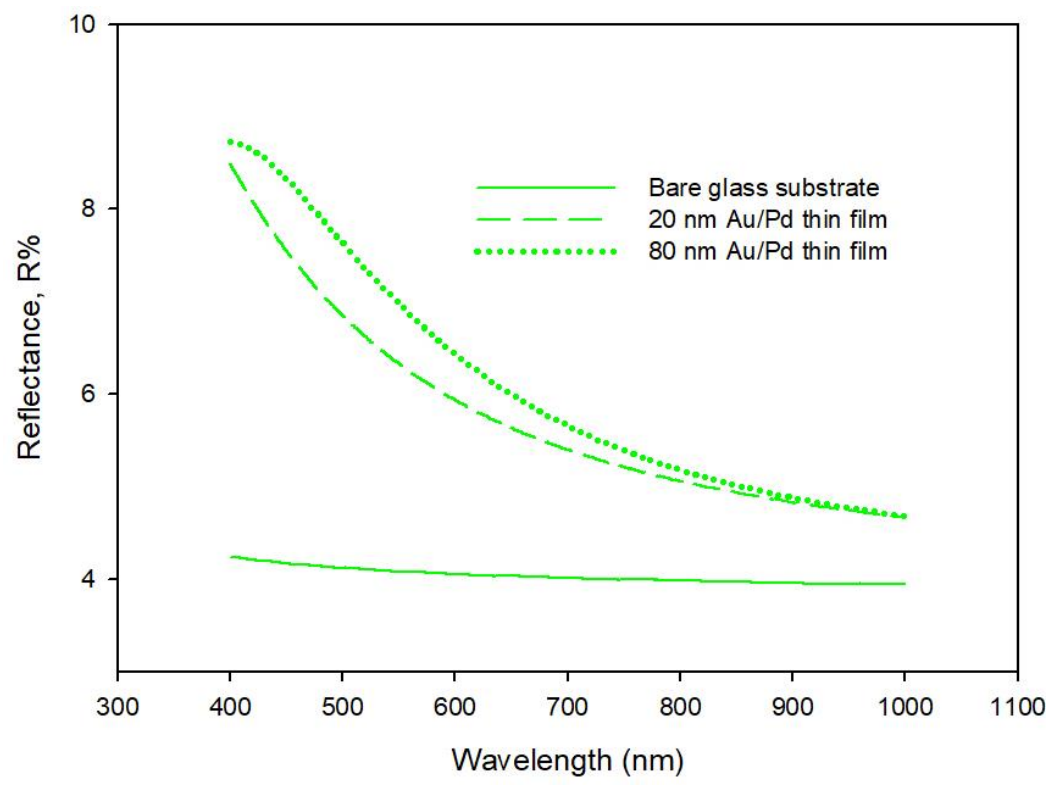

Figure 1. The reflectance spectra of the produced thin films

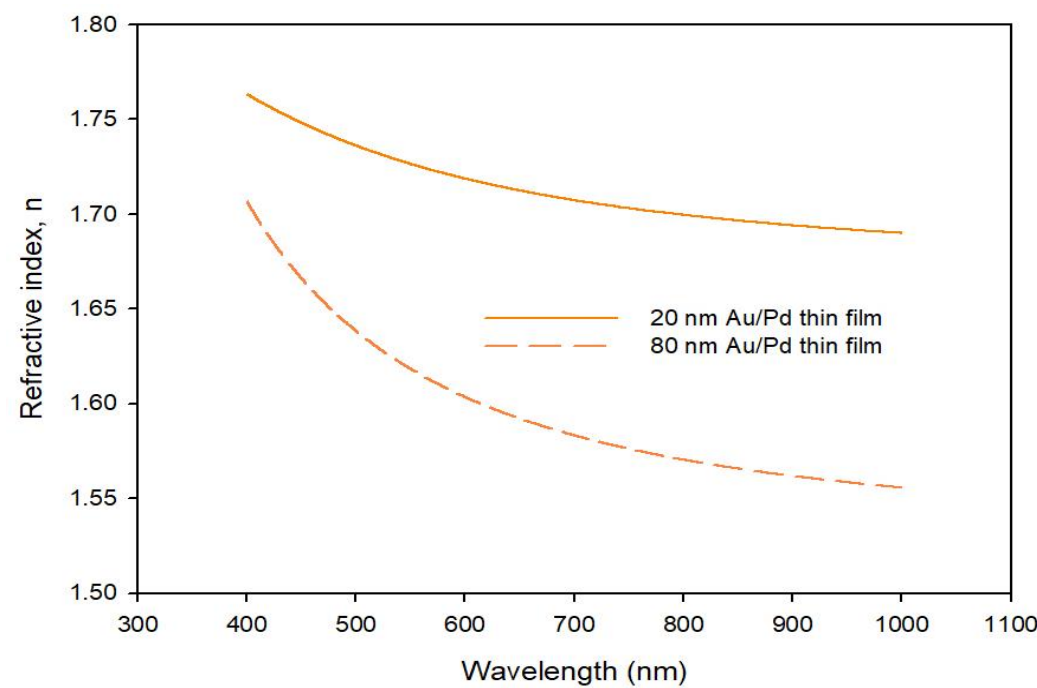

Figure 2. The refractive index distribution of the produced thin films 
Refractive index values of the produced $\mathrm{Au} / \mathrm{Pd}$ thin films versus wavelength are shown in Figure 2. Refractive index measurements were realized using Cauchy model. Cauchy equation for the refractive index is given by:

$\mathrm{n}(\lambda)=\mathrm{A}_{\mathrm{n}}+\mathrm{B}_{\mathrm{n}} / \lambda^{2}+\mathrm{C}_{\mathrm{n}} / \lambda^{4}$ and $\mathrm{k}(\lambda)=0$

where $A_{n}, B_{n}$ and $C_{n}$ are the fitting parameters used in Cauchy model. Although the refractive index values of both thin films decreased with the increasing wavelength, the refractive index of the thinner film was found to be higher than that of the thicker one. This result is due to the decreased packing density of the film with the increasing film thickness. Refractive index values at the wavelength of $550 \mathrm{~nm}$ were determined as 1.72 and 1.61 for $20 \mathrm{~nm}$ and 80 $\mathrm{nm}$ films, respectively. These values are higher than the refractive index values of the same material in the literature (DeSantis and Skrabalak, 2012).

\section{Ultraviolet and visible spectroscopy studies}

The transmittance and absorbance spectra of the bare glass substrate and the produced thin films are presented in Figure 3 and 4. It was observed that the transmittance value noticeably decreased and absorbance increased with the increasing thickness of the $\mathrm{Au} / \mathrm{Pd}$ thin film due to the thickness effect, because more states are available for the photons to be absorbed in relatively thicker films. The obtained absorbance values are lower than the absorbance values of the same material in the literature (Smith et al., 2016).

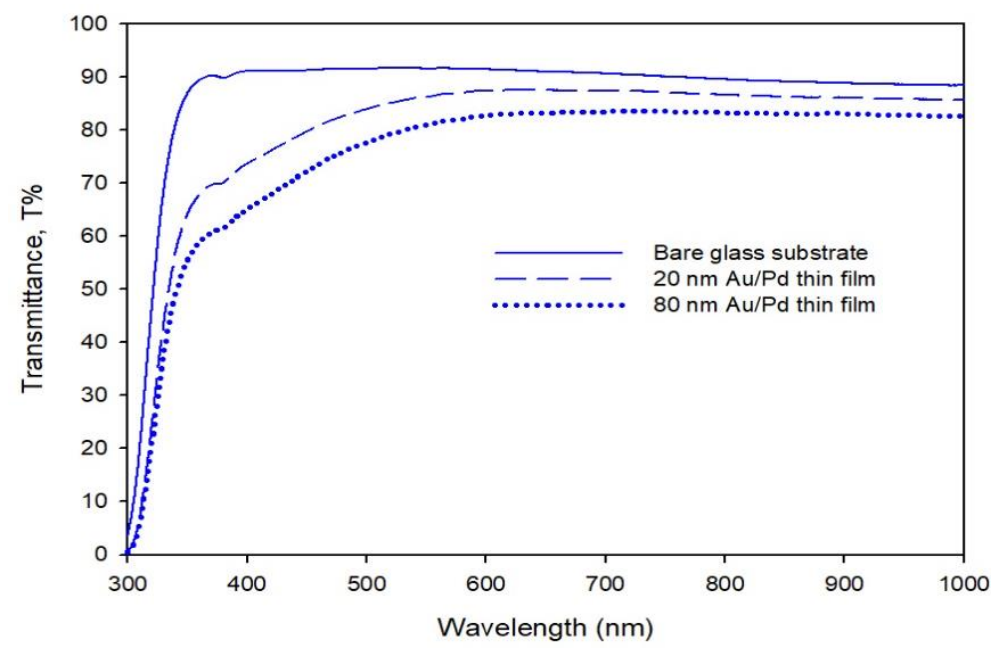

Figure 3. The transmittance spectra of the bare glass substrate and the produced thin films

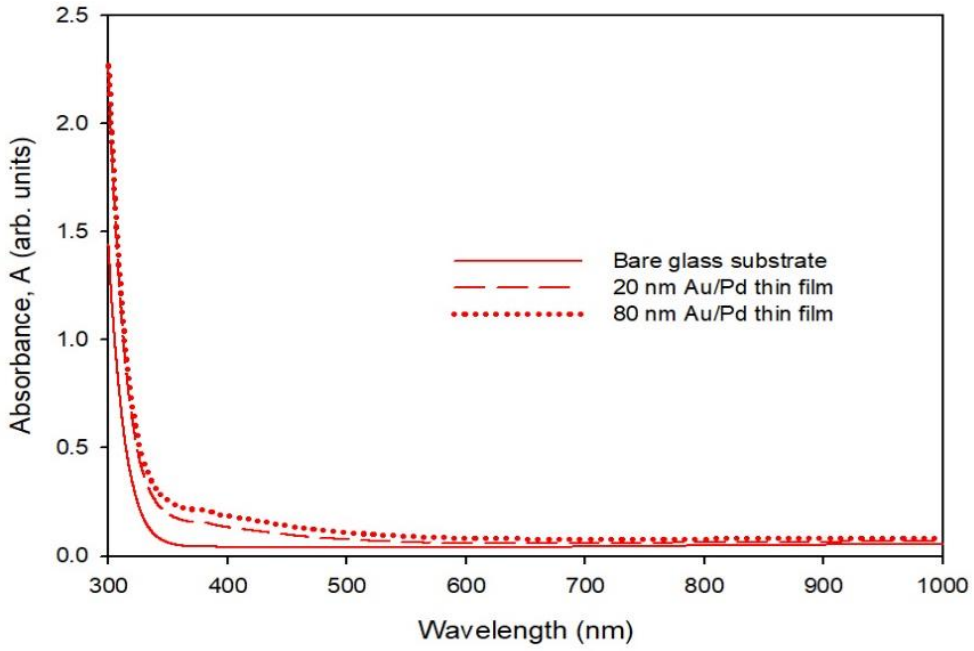

Figure 4. The absorbance spectra of the bare glass substrate and the produced thin films 


\section{Atomic force microscopy studies}

The obtained two-dimensional (2D) and three-dimensional (3D) AFM images are shown in Figure 5. 3D AFM images reveal that the produced $\mathrm{Au} / \mathrm{Pd}$ thin films are made up of needle-like grains. Root mean square (RMS) is an important parameter to describe the surface roughness by statistical methods. The mathematical definition and the digital implementation of this parameter are as follows:

$$
\begin{aligned}
& R_{q}=\sqrt{\frac{1}{l}} \int_{0}^{l}\{y(x)\}^{2} d x \\
& R_{q}=\sqrt{\frac{1}{n}} \sum_{i=1}^{n} y_{i}^{2}
\end{aligned}
$$

The RMS mean line is the line that divides the profile so that the sum of the squares of the deviations of the profile height from it is equal to zero. The RMS of the surface roughness of the produced films obtained from 40 lines on imaging scale are $5.31 \mathrm{~nm}$ and $8.24 \mathrm{~nm}$ for 20 $\mathrm{nm}$ and $80 \mathrm{~nm}$ films, respectively. These values are higher than the reported RMS values for the surfaces of $\mathrm{Au} / \mathrm{Pd}$ thin films produced via electron beam thermal evaporation by Nazarpour et al. (Nazarpour et al., 2010). As a result, the surface roughness of the synthesized $\mathrm{Au} / \mathrm{Pd}$ thin films increases with the increasing film thickness. This observation is in good agreement with relevant literature (Xin et al., 2010).
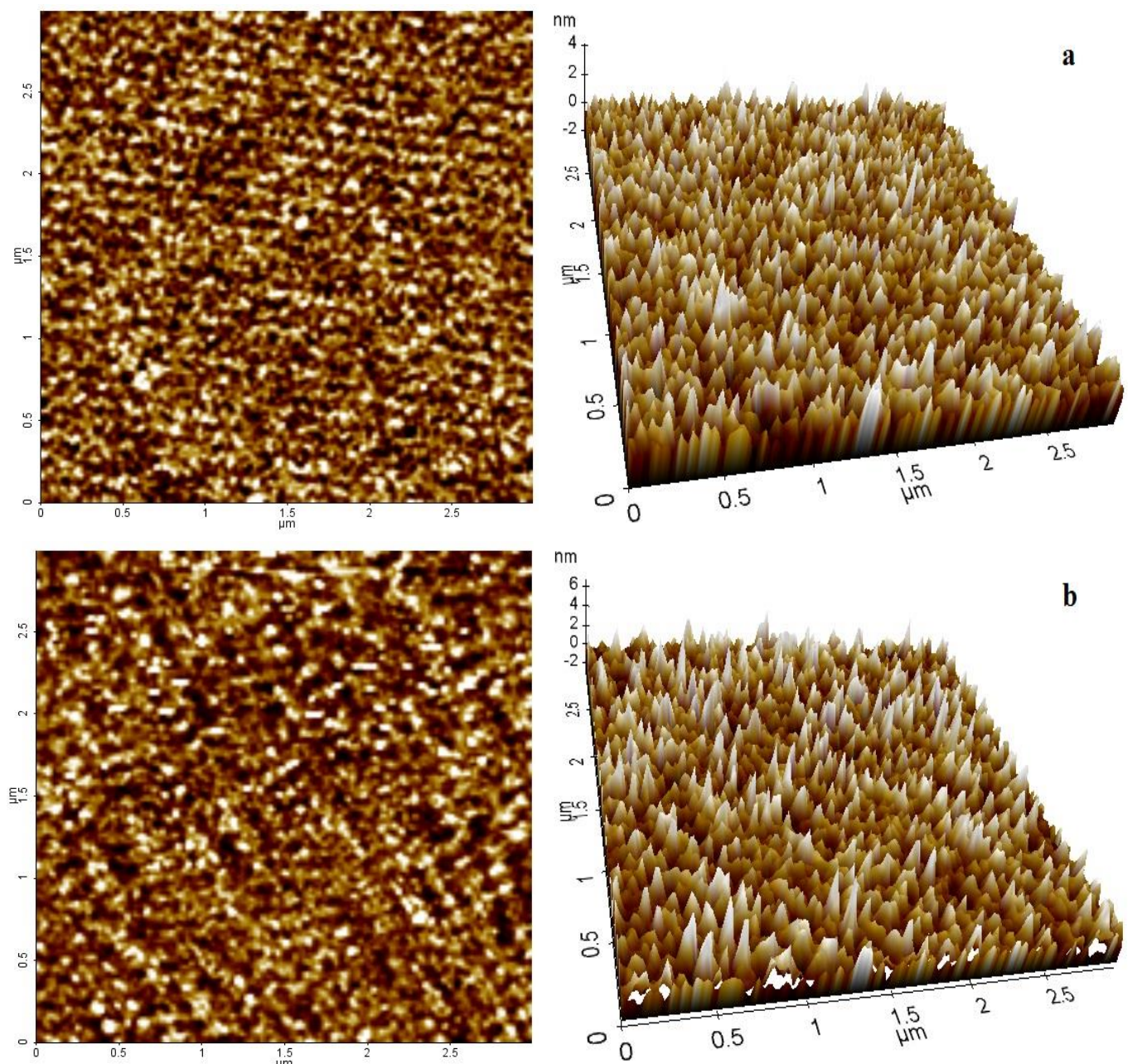

Figure 5. 2D and 3D AFM images of the produced (a) $20 \mathrm{~nm}$ and (b) $80 \mathrm{~nm}$ thin film 


\section{Wettability studies}

The interaction between deionized water drop and the surfaces of the produced $\mathrm{Au} / \mathrm{Pd}$ thin films were analyzed and the contact angles were found to be $77^{\circ}$ and $74^{\circ}$ for the $20 \mathrm{~nm}$ and the 80 $\mathrm{nm}$ thin films, respectively. When the water contact angle is smaller than $90^{\circ}$, the solid surface is considered hydrophilic. The photo images of the water drop on the film's surfaces are presented in Figure 6. The surface free energy (SFE) values of the thin films were measured as $35 \mathrm{~mJ} / \mathrm{m}^{2}$ for the $20 \mathrm{~nm}$ film and 37 $\mathrm{mJ} / \mathrm{m}^{2}$ for the $80 \mathrm{~nm}$ film. These values are lower than the SFE values of other materials in the literature (Jerman et al., 2010; Shin et al., 2012). The observation is that the surface morphology of the produced thin films affects the contact angle values. On needle-like surfaces, the contact angle value increases and the surface free energy value decreases.
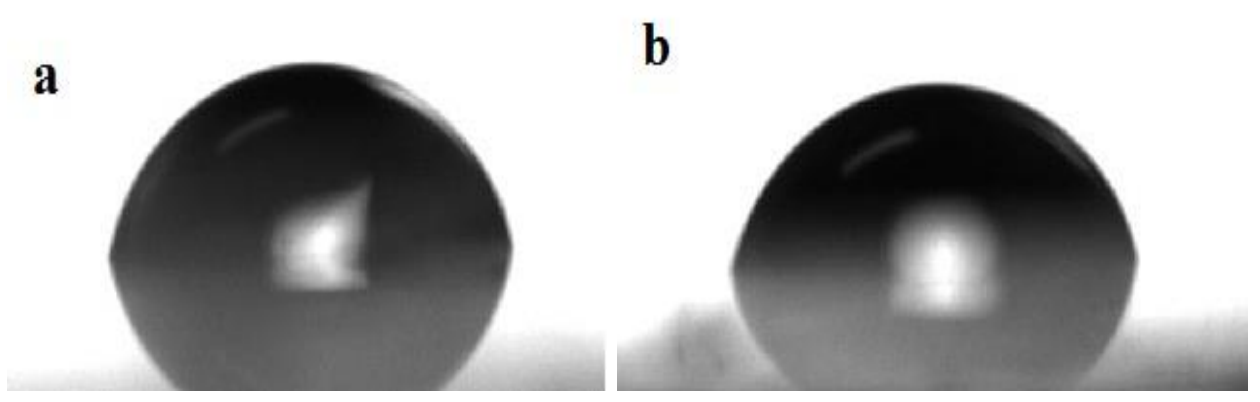

Figure 6. Photo images of water drop on the produced (a) $20 \mathrm{~nm}$ and (b) $80 \mathrm{~nm}$ thin film

\section{CONCLUSION}

In conclusion, two $\mathrm{Au} / \mathrm{Pd}$ thin films having different thickness values were deposited on glass substrates by means of RF magnetron sputtering technique. From the findings of the optical investigations, the films have high transmittance and low absorbance in the visible region as they are very thin layers. It was also observed that the reflectance and absorbance increase while transmittance and refractive index decreases with the increasing film thickness. The results of AFM studies show that the surfaces of the films are smooth (having low RMS roughness values) and homogenous with needlelike grains. However, roughness increases with increasing thickness. The surfaces of the produced $\mathrm{Au} / \mathrm{Pd}$ thin films have low SFE values and they show hydrophilic properties in wetting experiments.

\section{REFERENCES}

Bonet F, Delmas V, Grugeon S, Urbina RH, Silvert P, and Tekaia-Elhsissen, K, 1999. Synthesis of Monodisperse Au, Pt, Pd, Ru and Ir Nanoparticles in Ethylene Glycol. Nanostructured Materials, 11 (8): 12771284.

Chowdhury R, Mollick MMR, Biswas Y, Chattopadhyay D, and Rashid MH, 2018. Biogenic Synthesis of Shape-Tunable Au-Pd Alloy Nanoparticles with Enhanced Catalytic Activities. Journal of Alloys and Compounds, 763: 399-408.

Cybula A, Priebe JB, Pohl MM, Sobczak JW, Schneider M, Zielińska-Jurek A, Zaleska A, 2014. The Effect of Calcination Temperature on Structure and Photocatalytic Properties of $\mathrm{Au} / \mathrm{Pd}$ Nanoparticles Supported On $\mathrm{TiO}_{2}$. Applied Catalysis B: Environmental, 152: 202-211. 
de Yuso AM, Maetz A, Oumellal Y, Zlotea C, Le Meins JM and Ghimbeu CM, 2017. Optimization of The Synthesis of $\mathrm{Pd}-\mathrm{Au}$ Nanoalloys Confined in Mesoporous Carbonaceous Materials. Journal of Colloid And Interface Science, 505: 410-420.

DeSantis CJ, and Skrabalak SE, 2012. SizeControlled Synthesis of $\mathrm{Au} / \mathrm{Pd}$ Octopods With High Refractive Index Sensitivity. Langmuir, 28(24): 9055-9062.

Fedrigo S, Harbich W and Buttet J, 1993. Collective Dipole Oscillations in Small Silver Clusters Embedded in Rare-Gas Matrices. Physical Review B, 47(16): 10706.

Ferrer D, Torres-Castro A, Gao X, SepulvedaGuzman S, Ortiz-Mendez U, and JoseYacaman M, 2007. Three-Layer Core/Shell Structure In Au-Pd Bimetallic Nanoparticles. Nano Letters, 7(6): 1701-1705.

Henglein A, 2000. Colloidal Palladium Nanoparticles: Reduction of Pd (II) By H2; Pdcoreaushellagshell Particles. The Journal of Physical Chemistry B, 104(29): 66836685.

Hodak JH, Henglein A, Giersig M, and Hartland $\mathrm{GV}, 2000$. Laser-Induced Inter-Diffusion in Auag Core-Shell Nanoparticles. The Journal of Physical Chemistry B, 104(49): 1170811718

Hodak JH, Henglein A and Hartland GV, 2000. Coherent Excitation of Acoustic Breathing Modes in Bimetallic Core-Shell Nanoparticles. The Journal of Physical Chemistry B, 104(21): 5053-5055.

Jerman I, Koželj M and Orel B, 2010. The Effect of Polyhedral Oligomeric Silsesquioxane Dispersant and Low Surface Energy Additives on Spectrally Selective Paint Coatings With Self-Cleaning Properties. Solar Energy Materials and Solar Cells, 94(2): 232-245.

Kan C, Cai W, Li C, Zhang L and Hofmeister H, 2003. Ultrasonic Synthesis And Optical Properties Of Au/Pd Bimetallic Nanoparticles In Ethylene Glycol. Journal of Physics D: Applied Physics, 36(13): 1609.
Kreibig U and Vollmer M (1995). Theoretical Considerations Optical Properties of Metal Clusters, pp. 13-201, Springer.

Li C, Cai W, Kan C, and Fu G, 2004. Synthesis and Optical Characterization Of $\mathrm{Pd}-\mathrm{Au}$ Bimetallic Nanoparticles Dispersed Within Monolithic Mesoporous Silica. Scripta Materialia, 50(12): 1481-1486.

Mallikarjuna K, Bathula C, Reddy GD, Shrestha NK, Kim H And Noh YY, 2019. Au-Pd Bimetallic Nanoparticles Embedded Highly Porous Fenugreek Polysaccharide Based Micro Networks For Catalytic Applications. International Journal Of Biological Macromolecules, 126: 352-358.

Maye MM, Zheng W, Leibowitz FL, Ly NK and Zhong CJ, 2000. Heating-Induced Evolution of Thiolate-Encapsulated Gold Nanoparticles: A Strategy For Size and Shape Manipulations. Langmuir, 16(2): 490497.

Mizukoshi Y, Fujimoto T, Nagata Y, Oshima R and Maeda Y, 2000. Characterization and Catalytic Activity of Core-Shell Structured Gold/Palladium Bimetallic Nanoparticles Synthesized by the Sonochemical Method. The Journal of Physical Chemistry B, 104(25): 6028-6032.

Nazarpour S, Cirera A and Varela M, 2010. Material properties of $\mathrm{Au}-\mathrm{Pd}$ thin alloy films. Thin Solid Films, 518(20): 5715-5719. Palpant B, Prével B, Lermé J, Cottancin E, Pellarin M, Treilleux M, Perez A, Vialle JL and Broyer M, 1998. Optical Properties of Gold Clusters in the Size Range 2-4 Nm. Physical Review B, 57(3): 1963.

Parajuli P, Mendoza-Cruz R, Velazquez-Salazar JJ, Yacaman MJ and Ponce A, 2019. Fivefold Annealing Twin in Nanocrystalline $\mathrm{Au} / \mathrm{Pd}$ Film. Materials Letters, 244: 88-91.

Shao Gf, Tu Nn, Liu Td, Xu Ly, And Wen Yh, 2015. Structural Studies of $\mathrm{Au}-\mathrm{Pd}$ Bimetallic Nanoparticles by a Genetic Algorithm Method. Physica E: LowDimensional Systems And Nanostructures, 70: 11-20. 
Shishin B, Lee KR, Moon MW And Kim HY, 2012. Extreme Water Repellency of Nanostructured Low-Surface-Energy NonWoven Fabrics. Soft Matter, 8(6): 18171823.

Smith AF, Harvey SM, Skrabalak SE and Weiner RG, 2016. Engineering High Refractive Index Sensitivity Through the Internal and External Composition of Bimetallic Nanocrystals. Nanoscale, 8(38): 1684116845.

Szabo D and Vollath D, 1999. Nonocomposites from coated nanoparticles. Advanced Materials, 11(15): 1313-1316.

Toshima N, Harada M, Yamazaki Y and Asakura K, 1992. Catalytic Activity and Structural Analysis of Polymer-Protected GoldPalladium Bimetallic Clusters Prepared by the Simultaneous Reduction of Hydrogen Tetrachloroaurate and Palladium Dichloride. The Journal of Physical Chemistry, 96(24): 9927-9933.

Toshima N and Yonezawa T, 1998. Bimetallic Nanoparticles-Novel Materials For Chemical and Physical Applications. New Journal of Chemistry, 22(11): 1179-1201.
Wu ML, Chen DH and Huang TC, 2001. Synthesis Of $\mathrm{Au} / \mathrm{Pd}$ Bimetallic Nanoparticles In Reverse Micelles. Langmuir, 17(13): 38773883.

Xin Z, Xiao-Hui S and Dian-Lin Z, 2010. Thickness dependence of grain size and surface roughness for $\mathrm{dc}$ magnetron sputtered $\mathrm{Au}$ films. Chinese Physics B, 19(8): 086802.

Yi CW, Luo K, Wei T and Goodman D, 2005. The Composition and Structure Of $\mathrm{Pd}-\mathrm{Au}$ Surfaces. The Journal of Physical Chemistry B, 109(39): 18535-18540.

Zhang QX and Yin LB, 2012. Electrochemical Performance f Heterostructured Au-Pd Bimetallic Nanoparticles Toward As (III) Aqueous Media. Electrochemistry Communications, 22: 57-60. 